\title{
The Impact Of Country-Level vs Firm-Level Factors On The Effectiveness Of IFRS Adoption: The Case Of European Union
}

Kanogporn Narktabtee, National Institute of Development Administration, Thailand Suntaree Patpanichchot, National Institute of Development Administration, Thailand

\begin{abstract}
The mandatory adoption of IFRS has been encouraged worldwide, with the objective to enhance the quality of accounting information. However, this effort is challenged by the argument that several factors affecting financial reporting incentives still vary across countries. Also, Gaio (2010) indicates that firm-level factors also have significant explanatory power on earning quality. Therefore, it is doubtful whether the mandatory adoption of IFRS can always lead to better quality of accounting information.

This paper examines the effect of country-level and firm-level factors on value relevance of earnings and book value of equity. Among several country-level factors, this paper focuses on investor protection - proxied by anti-director right index (La Porta et al., 1998). In this study, firm-level factors refer to firm characteristics which allow or induce high use of managerial discretion. These characteristics are proxied by firm size, cash flow volatility, sales volatility, and incidence of negative earnings.

Different from prior literatures which focus on "level" of value relevance, this paper examines the effect of country-level and firm-level factors on "change" in value relevance of earnings and book value of equity, arisen from the mandatory adoption of IFRS in the year 2005. By comparing value relevance of earnings and book value of equity among European Union countries during the years 1999-2007, the results indicate that the adoption of IFRS leads to improvement in value relevance. In addition, both country-level and firm-level factors have significant influence on the degree of improvement in value relevance from the IFRS adoption. In particular, the firms which operate in a weak investor protection environment and have firm characteristics which induce or allow the managers to use high managerial discretion (i.e., small size, high cash flow volatility, high sales volatility, and frequent incidences of loss) do not experience significant improvement in value relevance from IFRS adoption.
\end{abstract}

The results imply that the IFRS adoption does not ensure better quality of accounting information. The improvement of the quality of accounting information depends on both country and firm characteristics, which influence financial reporting incentives.

Keywords: IFRS Adoption; Value Relevance; European Union

\section{INTRODUCTION}

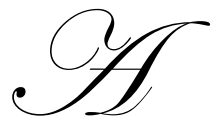

ccounting standard harmonization has become an important issue worldwide, as evidenced by the mandatory adoption of IFRS in several countries as well as the effort toward convergence of IFRS and U.S. GAAP. Accounting standard harmonization is motivated with the objective to enhance the usefulness of accounting information, in term of relevance and comparability. The importance of accounting standard is evidenced in several prior studies. Their findings suggest that the quality of accounting information 
varies across different accounting standards (Alford et al., 1993; Joos and Lang, 1994) and the quality of accounting information is better for firms adopting IAS or U.S. GAAP than those adopting domestic accounting standards (Amir et al., 1993; Auer, 1996; Ashbaugh and Pincus, 2001; Barth et al., 2008).

However, many researchers question the success of current accounting standard harmonization efforts, especially in the environment where several factors affecting the financial report preparer's incentives remain unchanged and vary across countries and firms. In term of country-level factor, prior literature indicates that legal and market factors determine investor protection (La Porta et al., 1997 and 1998), which influences the financial report preparer's incentives to choose accounting policy and to exercise their managerial discretion. In turn, legal and market factors affect the quality of accounting information (for example, Ali and Hwang, 2000; Hung, 2001; Fan and Wong, 2002; Luez et al., 2003). Therefore, under different legal and market structure which leads to different level of investor protection mechanisms, the expected outcome from accounting standard harmonization may not be achieved if accounting standard convergence occurs on paper only, rather than at practice level.

In addition to country-level factor, earnings quality is related to firm characteristics (Gaio, 2010). Firm characteristics can determine level of uncertainty and, in turn, the degree of managerial discretion the financial report preparer can exercise (Dechow and Dichev, 2002). High cash flow volatility and high sales volatility imply greater uncertainty in the firm's operation, which provides opportunity for the managers to use greater judgment. In addition, firm size influences level of information search by investors and financial analysts. More information search is expected for large firm, resulting in high demand for accounting information. Since these firm characteristics can influence the financial report preparer's incentive, and in turn, the quality of accounting information, it is doubtful whether the mandatory adoption of IFRS leads to similar improvement for firms with different characteristics.

To examine the impact of country-level and firm-level factors on the effectiveness of IFRS adoption, this study evaluates the change in value relevance of earnings and book value of equity during pre- and post-IFRS adoption under different country-level and firm-level characteristics. Value relevance of earnings and book value of equity is used as a proxy for the quality of accounting information. Given the importance on capital markets, valuerelevant information is useful for investors in evaluating the past, present and future of the firms and in making equity investment decision.

The scope of this study focuses on listed firms in European Union countries during the year 1999 to 2007. Listed firms in European Union (EU) countries have been required to prepare their financial reports according to International Financial Reporting Standards (IFRS), starting from the year 2005. Therefore, pre- vs post-IFRS adoption test under this setting (Pre-IFRS period: years 1999-2004 vs Post-IFRS period: years 2005-2007) allows us to measure the improvement in value relevance resulting from IFRS adoption.

The sample is partitioned into 4 groups depending on the scores of their country-level and firm-level factors. For country-level factor, we use anti-director right index by La Porta et al. (1998) to represent level of investor protection. A set of firm characteristics (i.e. firm size, cash flow from operation volatility, sales volatility, and incidence of negative earnings) are used to compute firm-level score, since prior literature indicates that these firm characteristics influence the use of managerial discretion. Then, for each groups, we run price regression for pre- and post-IFRS period to measure the change in value relevance of earnings and book value of equity.

Our evidence suggests that the adoption of IFRS leads to improvement in value relevance in all cases except the case where the firms operate in weak investor protection environment and have firm characteristics which induce or allow the managers to use high managerial discretion (i.e. small firm size, high cash flow volatility, high sales volatility, and more frequent incidence of negative earnings). The result highlights the importance of both country-level and firm-level factors on the effectiveness of IFRS adoption.

This study has contributions to accounting literature. Different from prior literatures which focus on "level" of value relevance, this paper examines the effect of "both country-level and firm-level factors" on "change" in value relevance of earnings and book value of equity, resulting from the mandatory adoption of IFRS. This study extends existing researches on IFRS adoption by incorporating both country-level and firm-level factors into the 
analysis. Our findings provide useful information in response to current trend of accounting standard harmonization. The findings that value relevance improves after the shift to IFRS guarantee the benefit of current accounting standard harmonization efforts, i.e. the mandatory adoption of IFRS. On the other hand, our findings that the improvement does not always occur but depends on country-level and firm-level characteristics, challenge the effort of accounting standard harmonization.

The findings also have implications for standard setters and users of accounting information. The mandatory adoption of IFRS does not guarantee high quality of accounting information, especially in case where firm characteristics induce or allow the managers to use high managerial discretion. This is consistent with prior studies, which found that earning quality can be affected by firm characteristics. Moreover, the findings highlight the importance of investor protection as a tool to reduce the financial report preparer's incentives to manipulate accounting numbers. Therefore, it is important for standard setters and regulators to strengthen their market and legal mechanisms in order to enhance investor protection and to ensure the compliance with standards.

\section{LITERATURE REVIEW AND HYPOTHESIS DEVELOPMENT}

The quality of accounting information has been extensively investigated by using different properties, ranging from value relevance, timeliness and conservatism, accruals quality, earnings persistence, earnings predictability, and earnings smoothness. Prior literatures found that these accounting information attributes are affected by several factors, such as accounting standard (Alford et al., 1993; Joos and Lang, 1994; Amir et al., 1993; Auer, 1996; Ashbaugh and Pincus, 2001; Barth et al., 2008), country-level factors such as legal and market structure (Boonlert-U-Thai et al., 2006; Ali and Hwang, 2000; Hung, 2001; Bushman and Piotroski, 2006; Defond et al., 2007), and firm-level factors (Gaio, 2010). In this paper, pre- vs post-IFRS adoption test allows us to investigate the effect of accounting standard on value relevance of earnings and book value of equity - our chosen proxy for the quality of accounting information. More importantly, we incorporate country-level and firm-level factors to examine whether the improvement (if any) in value relevance, resulting from IFRS adoption, depends on countrylevel and firm-level factors.

\section{Country-level Factor}

Ball (2006) expressed concerns that IFRS implementation may not be equal across different countries, since their legal and market factors remain local and vary across different countries. These legal and market factors play important role on the quality of accounting information, since they affect the financial report preparer's incentive. The key mechanism behind this linkage is investor protection.

In term of legal factors, legal rules and enforcement shape the degree of investor protection, which determines cost and benefit of expropriation against minority shareholders by controlling shareholders. La Porta et al. (2000 and 2002) explain that, under the concept of "cost versus benefit of expropriation", the insiders - both controlling shareholders and managers - have private benefit of control to expropriate against minority shareholders. However, this benefit is negatively related to investor protection. When the level of shareholder protection is high, the insiders are forced to use more complicated technique in order to expropriate against minority shareholders. This raises cost of expropriation and reduces the insiders' benefit from expropriation. As strong investor protection discourages the insiders to expropriate against minority shareholders, it reduces their incentives to manipulate accounting numbers in order to conceal their private benefits of control from the outsiders. Therefore, strong investor protection is associated with high quality accounting information (for example, Hung, 2001; Luez et al., 2003).

In terms of market factors, investor protection has an impact on corporate ownership structure and financial market development. Strong investor protection reduces expropriation risk and increases investors' confidence. This results in highly-developed financial markets and diverse corporate shareholding structures, which lead to high demand for public information. Prior researches (for example, Fan and Wong, 2002; Luez et al., 2003) found high quality of accounting information in such circumstance. 
Therefore, different legal and market structure in each country reflects its own level of investor protection, which has influence on the financial report preparer's incentives, and in turn, the quality of accounting information.

\section{Firm-level Factor}

Gaio (2010) suggest that firm characteristics play important role in explaining the variation in earnings quality. This is consistent with prior researches (Dechow and Dichev, 2002; Atiase, 1985; Freeman, 1987), which found the association between firm characteristics and accounting information attributes.

Dechow and Dichev (2002) found that accrual quality is negatively related with sales volatility and cash flow volatility, and is positively related with firm size. Sales volatility and cash flow volatility imply high uncertainty in operating environment, while small firm size implies less stable and predictable operations the firms have. In such circumstance, greater uncertainty exists, and consequently, more managerial judgment is needed, which could negatively affect accrual quality. In addition, Minton (1999) found that cash flow volatility increases cost of external fund raising. In term of firm size, Eierle and Haller (2009) view firm size as a proxy for the number and heterogeneity of financial statement users. Larger firms are associated with larger user groups and, in turn, higher demand for extensive and detailed information in financial statements. In addition, firm size is conceived as a proxy for stakeholder structures. Smaller firms usually reflect concentrated ownership pattern, which allows their shareholders to directly access information, resulting in less reliance on public financial information. As a result, firm size affects incentive for private information search by investors, financial press and analysts. Private information production is increasing function of firm size. Atiase (1985) found that the information content of quarterly earnings releases is inversely related to firm size. Freeman (1987) also found that magnitude of abnormal returns related to accounting earnings is inversely related to firm size. Information search leads to high demand for accounting information, and influences the financial report preparer's incentive.

Since these firm characteristics affect the degree of uncertainty of the firm's operation, funding cost, and the degree of information search by investors and financial analysts, these firm characteristics influence the financial report preparer's incentive to exercise their managerial discretion.

Since investor protection and firm characteristics affect the incentive of financial report preparer, theses factors are more likely to have influence on the improvement in the quality of accounting information, resulting from IFRS adoption. This raises concern that IFRS adoption may not always lead to improvement in the quality of accounting information - in this paper, value relevance. Accordingly, null hypothesis is developed as follows:

$\mathbf{H}_{\mathbf{0}}$ : Improvement in value relevance of earnings and book value of equity from IFRS adoption is significant, regardless of the level of investor protection in the country and the characteristics of the firms.

This hypothesis could be supported by prior literatures which found that adopting international accounting standards improves the quality of accounting information. However, the hypothesis could be rejected, due to fair value accounting embedded in IFRS. While fair value accounting contains more information than historical cost accounting, it requires an increased amount of judgment, which in turn provides some room for accounting manipulation. Callao and Jarne (2010) found that earning management has intensified since the adoption of IFRS. This increased discretion raises concern over the consistency of the application of accounting standards and accounting manipulation. With the variation of investor protection and firm characteristics affecting the incentive of financial report preparers and the degree of accounting manipulation, the success of IFRS adoption could vary across different environment. It is predicted that value relevance improves after IFRS adoption under the environment where investor protection and firm characteristics discourage accounting manipulation. On the other hand, the improvement in value relevance may not occur, particularly for the firms which operate in weak investor protection environment and have firm characteristics that allow or induce high use of managerial discretion. 


\section{RESEARCH DESIGN}

\section{Sample}

The initial sample is non-financial firms, with fiscal year ending on December 31, which are listed in European Union stock exchanges during the years 1999 - 2007. We include only the firms of which the country of incorporation is the same as the country of the stock exchange on which the firms are listed, in order to exclude cross-listed firms. Price and accounting data required for price regression and firm-level score computation are extracted from Compustat database. The firms with incomplete data are excluded.

To examine the improvement in value relevance resulting from IFRS adoption, we focus only on firms which changed their accounting standard from domestic accounting standards to IFRS in the year 2005. For screening purpose, we use "Accounting Standard Code" available in Compustat database. This code identifies accounting standards which the company uses in presenting its financial statement. DS represents "Domestic Standards" (which is our main focus for the years 1999 to 2004), while DI represents "Domestic standards generally in according to International Accounting Standards Committee (IASC) guidelines" (which is our criterion for the years 2005 to 2007). Outliers are identified as the top and bottom $1 \%$ of observations for each variable, and the firms identified as outlier are excluded from the sample. Final sample consists of 406 firms from 15 countries during the years 1999-2007, or 3,654 firm-years in total.

\section{Methodology}

Timeframe of the analysis

In our analysis, the sample is divided into three intervals:

1. From the years 1999 to 2001 (Pre-IFRS adoption). The European Union Parliament officially announced the mandatory adoption of IFRS in the year 2002. Standard setters and firms could prepare for the year 2005 requirement by gradually converging their domestic accounting standards to IFRS during the years 2002-2004. Therefore, we extend our sample period to years 1999-2001, i.e. the period before the European Union Parliament officially announced the requirement for the mandatory adoption of IFRS, in order to exclude the effect of such preparation effort.

2. From the years 2002 to 2004 (Preparation period). This is also classified as the pre-IFRS adoption period, but it represents the period after the requirement for the mandatory adoption of IFRS was formally announced.

3. From the years 2005 to 2007 (Post-IFRS adoption).

\section{Group classification}

To examine the hypothesis which is related to country-level and firm-level factors, the sample is divided into 4 groups, depending on investor protection and firm characteristics which determine the use of managerial discretion.

Group $1(\mathrm{WH})$ : Firms which operate in the country with weak investor protection (W) and have firm characteristics which allow or induce high use of managerial discretion $(\mathrm{H})$.

Group 2 (SH): Firms which operate in the country with strong investor protection (S) but have firm characteristics which allow or induce high use of managerial discretion $(\mathrm{H})$.

Group 3 (WL): Firms which operate in the country with weak investor protection (W) and have firm characteristics which allow or induce low use of managerial discretion (L).

Group 4 (SL): Firms which operate in the country with strong investor protection (S) and have firm characteristics which allow or induce low use of managerial discretion (L). 
Figure 1: Classification Based On Investor Protection And Firm Characteristics

\begin{tabular}{|c|c|c|c|c|}
\hline \multicolumn{5}{|c|}{ Investor protection } \\
\hline \multirow{4}{*}{ 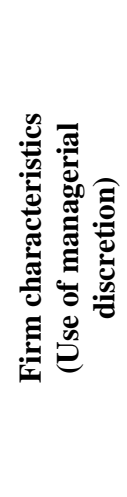 } & & Weak & Strong & Total \\
\hline & High & $\begin{array}{l}\text { - Weak investor protection }(\mathrm{W}) \\
\text { - Firm characteristics which allow } \\
\text { high use of managerial discretion }(\mathrm{H}) \\
\text { Group WH (78 firms) }\end{array}$ & $\begin{array}{l}\text { - Strong investor protection }(\mathrm{S}) \\
\text { - Firm characteristics which allow } \\
\text { high use of managerial discretion }(\mathrm{H}) \\
\text { Group SH (126 firms) }\end{array}$ & 204 firms \\
\hline & Low & $\begin{array}{l}\text { - Weak investor protection (W) } \\
\text { - Firm characteristics which allow } \\
\text { low use of managerial discretion (L) } \\
\text { Group WL (59 firms) }\end{array}$ & $\begin{array}{l}\text { - Strong investor protection (S) } \\
\text { - Firm characteristics which allow } \\
\text { low use of managerial discretion (L) } \\
\text { Group SL (143 firms) }\end{array}$ & 202 firms \\
\hline & Total & 137 firms & 269 firms & \\
\hline
\end{tabular}

Notes:

1. The sample is divided into 4 groups, based on level of investor protection and firm characteristics which determine the use of managerial discretion.

Group WH: Firms which operate in the country with weak investor protection (W) and have firm characteristics which allow/induce high use of managerial discretion $(\mathrm{H})$.

Group SH: Firms which operate in the country with strong investor protection (S) but have firm characteristics which allow/induce high use of managerial discretion $(\mathrm{H})$.

Group WL: Firms which operate in the country with weak investor protection (W) and have firm characteristics which allow/induce low use of managerial discretion (L).

Group SL: Firms which operate in the country with strong investor protection (S) and have firm characteristics which allow/induce low use of managerial discretion (L).

2. For investor protection, anti-director rights index is used to partition the sample. This index is developed by La Porta et al. (1998) to measure how well the mechanisms are in place to protect minorities shareholders. The mean of index for our country sample is used as the cutoff point. S (Strong) is assigned for the countries with the score higher than the mean of index for our country sample, and $\mathrm{W}$ (Weak) is assigned for the countries with the score below mean.

3. For firm characteristics which determine the use of managerial discretion, the score is computed based on four firm characteristics, i.e. average firm size, cash flow from operation volatility, sales volatility, and incidence of negative earnings. For each variable, the sample is ranked. Low rank is assigned for the firms with low managerial incentive for accounting manipulation, i.e. large firm size, low sales volatility, low cash flow volatility and low incidence of negative earnings. Then, the ranks based on these 4 variables are averaged in order to get the score. Mean of this score is used as the cutoff point.

\section{Variables Used for Partitioning}

In order to classify sample into four groups based on level of investor protection and firm characteristics, we use the following variables:

1. Investor protection: The anti-director rights index, developed by La Porta et al. (1998) in order to measure how well the mechanisms are in place to protect minorities shareholders, is used to partition the sample. The mean of index for our country sample is used as the cutoff point for weak versus strong investor protection groups. The median, if employed, results in the same partition.

2. Firm characteristics: four firm characteristics used in prior research are used, i.e. firm size, cash flow volatility, sales volatility, and incidence of negative earnings. Size is average of total assets of each firm during the sample period. Cash flow volatility is the standard deviation of cash flow from operation. Sales volatility is the standard deviation of sales revenues. Incidence of negative earnings is the number of negative earnings during the sample period. 
For each variable, the sample is ranked. Low rank is assigned for the firms with low managerial incentive for accounting manipulation, i.e. large firm size, low sales volatility, low cash flow volatility and low incidence of negative earnings. Then, the ranks based on these 4 variables are averaged in order to get the score representing firm-level managerial incentive. This score is used in partitioning. The mean value of this score is used as the cut-off point. As a result, the sample can be divided into 2 groups, i.e. those with the firm characteristics that allow or induce "high vs low" use of managerial discretion.

Table 1 presents sample classification by level of investor protection and firms characteristics.

Table 1: Country Classification Based On Investor Protection And Firm Characteristics

\begin{tabular}{|c|c|c|c|c|c|}
\hline & \multirow{3}{*}{ Country } & \multicolumn{2}{|c|}{ Investor protection } & \multirow{2}{*}{\multicolumn{2}{|c|}{$\begin{array}{c}\text { Number of firms } \\
\text { Classified by firm characteristics } \\
\text { (Use of managerial discretion) }\end{array}$}} \\
\hline & & \multirow{2}{*}{$\begin{array}{c}\text { Anti-director rights } \\
\text { index }\end{array}$} & \multirow[t]{2}{*}{ Weak vs Strong } & & \\
\hline & & & & High & Low \\
\hline 1. & Austria & 2 & $\mathrm{~W}$ & 1 & 1 \\
\hline 2. & Belgium & 0 & $\mathrm{~W}$ & 3 & 5 \\
\hline 3. & Denmark & 2 & $\mathrm{~W}$ & 4 & 4 \\
\hline 4. & Germany & 1 & $\mathrm{~W}$ & 24 & 9 \\
\hline 5. & Greece & 2 & $\mathrm{~W}$ & 8 & 6 \\
\hline 6. & Italy & 1 & $\mathrm{~W}$ & 14 & 19 \\
\hline 7. & Netherlands & 2 & $\mathrm{~W}$ & 24 & 15 \\
\hline & & & & 78 & 59 \\
\hline 8. & Finland & 3 & $\mathrm{~S}$ & 12 & 12 \\
\hline 9. & France & 3 & $\mathrm{~S}$ & 34 & 51 \\
\hline 10. & Ireland & 4 & $\mathrm{~S}$ & 3 & 4 \\
\hline 11. & Norway & 4 & $\mathrm{~S}$ & 7 & 11 \\
\hline 12. & Portugal & 3 & $\mathrm{~S}$ & 3 & 3 \\
\hline 13. & Spain & 4 & $\mathrm{~S}$ & 0 & 2 \\
\hline 14. & Sweden & 3 & $\mathrm{~S}$ & 15 & 11 \\
\hline 15. & UK & 5 & $\mathrm{~S}$ & 52 & 49 \\
\hline & & & & 126 & 143 \\
\hline & Mean & 2.6 & & 204 & 202 \\
\hline
\end{tabular}

Notes:

1. For investor protection (country-level factor), anti-director rights index is used to partition the sample. This index is developed by La Porta et al. (1998) to measure how well the mechanisms are in place to protect minorities shareholders. The mean of index for our country sample is used as the cutoff point. S (Strong) is assigned for the countries with the score higher than the mean, and $\mathrm{W}$ (Weak) is assigned for the countries with the score below mean.

2. For firm characteristics which determine the use of managerial discretion, the score is computed based on four firm characteristics, i.e. average firm size, cash flow from operation volatility, sales volatility, and incidence of negative earnings. For each variable, the sample is ranked. Low rank is assigned for the firms with low managerial incentive for accounting manipulation, i.e. large firm size, low sales volatility, low cash flow volatility and low incidence of negative earnings. Then, the ranks based on these 4 variables are averaged in order to get the score. Mean of this score is used as the cutoff point.

Table 2 reports descriptive statistics of four firm characteristics. In Panel A, wide range of value of these variables confirms that the sample firms have apparently different characteristics, and therefore, are valid for our classification. Panel B reports mean value of these firm characteristics for 2 sub-samples, classified based on the firm characteristics which determine the use of managerial discretion. Group "High" (i.e. the firms of which the characteristics allow or induce high use of managerial discretion) has smaller average firm size, larger average cash flow volatility, larger average sales volatility and more frequent incidence of negative earnings than Group "Low" (i.e. the firms of which the characteristics allow or induce low use of managerial discretion). The t-statistics indicate that mean differences are significant for all four firm characteristics. The findings support the validity of using these firm characteristics for the classification. 
Table 2: Descriptive Statistics Of Firm Characteristics

Panel A: Pooled Data

\begin{tabular}{|c|c|c|c|}
\hline & Minimum & Maximum & Mean \\
\hline Size (Total assets: USD million) & 9.01 & $194,720.00$ & $3,934.57$ \\
\hline Cash flow volatility & 0.01 & 0.18 & 0.05 \\
\hline Sales volatility & 0.02 & 0.91 & 0.20 \\
\hline Incidence of negative earnings & 0 & 1.00 & 0.12 \\
\hline
\end{tabular}

Panel B: By Groups Classified Based on Firm Characteristics

\begin{tabular}{|l|c|c|c|c|}
\hline & \multicolumn{2}{|c|}{ Mean } & \multirow{2}{*}{ Difference } & \multirow{2}{*}{ t-statistics } \\
\hline Size (Total assets: USD million) & High & Low & $(6,382.81)$ & $(15.22)^{* *}$ \\
\hline Cash flow volatility & 758.88 & $7,141.69$ & 0.04 & $37.96^{* *}$ \\
\hline Sales volatility & 0.07 & 0.03 & 0.13 & $30.27^{* *}$ \\
\hline Incidence of negative earnings & 0.26 & 0.13 & 0.12 & $24.85^{* *}$ \\
\hline
\end{tabular}

Notes:

1. Variable definition is as follows:

- $\quad$ Size is average of total assets of each firm during the sample period (USD million).

- Cash flow volatility is the standard deviation of cash flow from operation of each firm.

- Sale volatility is the standard deviation of sales revenues of each firm.

- Incidence of negative earnings is the number of negative earnings of each firm during the sample period.

2. In Panel B, the sample is divided into 2 groups, based on firm characteristics which determine the use of managerial discretion. High (Low) represents the group of firms with the characteristics that allow or induce high (low) use of managerial discretion.

3. Panel B reports t-statistics for equality of means. $* *$ and * denote $5 \%$ and $10 \%$ significance, respectively (two-tailed).

\section{Model Specification}

To test the hypothesis, we examine whether there is any significant improvement in value relevance during three periods for each group. Therefore, the following price regression - based on the valuation framework by Ohlson (1991) - will be conducted for each group and each period.

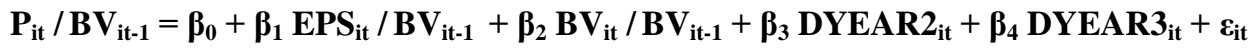

where:

$P_{i t}$ is the market price of firm $i$ at balance sheet date $t$ plus two months.

$\mathrm{BV}_{\mathrm{it}}$ is book value of equity per share of firm $\mathrm{i}$ at year $\mathrm{t}$

$\mathrm{EPS}_{\mathrm{it}}$ is earnings per share of firm $\mathrm{i}$ at the end of year $\mathrm{t}$.

DYEAR $2_{\text {it }}$ is the dummy variable for Year 2 in each period, which is equal to 1 if time ' $t$ ' is equal to year 2000, 2003 , or 2006, and 0 otherwise.

DYEAR $3_{\text {it }}$ is the dummy variable for Year 3 in each period, which is equal to 1 if time ' $t$ ' is equal to year 2001, 2004, or 2007, and 0 otherwise.

The improvement in value relevance is measured by the change in adjusted $\mathrm{R}^{2}$, and Z-statistics is used to determine whether the difference of adjusted $\mathrm{R}^{2}$ between two sub-periods is significant (Harris et al., 1994; Arce and Mora, 2002).

$Z=\frac{R_{1}^{2}-R_{2}^{2}}{\sqrt{\sigma_{\left(R^{2} 1\right)}^{2}+\sigma_{(R 2)}^{2}{ }^{2}}}$

$\mathrm{R}^{2}{ }_{1}$ and $\mathrm{R}_{2}^{2}$ are the $\mathrm{R}^{2}$ from the regressions of the subsamples being compared. $\sigma_{(.)}^{2}$ is their variance, which is calculated based on Cramer (1987). 


\section{RESULTS}

\section{Descriptive Statistics}

Table 3: Descriptive Statistics And Pearson Correlation Of Dependent And Independent Variables

Panel A: Descriptive Statistics

\begin{tabular}{|c|c|c|c|c|c|c|c|c|c|c|}
\hline & & \multicolumn{3}{|c|}{ Price (Scaled) } & \multicolumn{3}{c|}{ EPS (Scaled) } & \multicolumn{3}{c|}{ BV (Scaled) } \\
\hline Group & Period & & & Standard & & & Standard & & \multicolumn{2}{c|}{ Standard } \\
\hline & & Mean & Median & deviation & Mean & Median & deviation & Mean & Median & deviation \\
\hline Pool & Pool & 2.52 & 1.89 & 2.15 & 0.13 & 0.13 & 0.15 & 1.12 & 1.11 & 0.23 \\
\hline Pool & 1 & 2.47 & 1.57 & 2.68 & 0.13 & 0.13 & 0.14 & 1.02 & 1.00 & 0.21 \\
\hline & 2 & 2.25 & 1.80 & 1.70 & 0.11 & 0.11 & 0.15 & 1.18 & 1.18 & 0.21 \\
\hline & 3 & 2.83 & 2.40 & 1.89 & 0.17 & 0.16 & 0.15 & 1.16 & 1.17 & 0.25 \\
\hline WH & 1 & 2.06 & 1.45 & 2.18 & 0.10 & 0.09 & 0.15 & 0.98 & 0.94 & 0.26 \\
\hline & 2 & 1.79 & 1.51 & 1.40 & 0.07 & 0.08 & 0.17 & 1.18 & 1.18 & 0.27 \\
\hline & 3 & 2.48 & 2.07 & 1.75 & 0.14 & 0.13 & 0.17 & 1.16 & 1.17 & 0.25 \\
\hline SH & 1 & 2.32 & 1.43 & 2.70 & 0.11 & 0.10 & 0.17 & 1.02 & 1.01 & 0.21 \\
\hline & 2 & 2.21 & 1.75 & 1.65 & 0.10 & 0.10 & 0.16 & 1.16 & 1.15 & 0.20 \\
\hline & 3 & 2.83 & 2.43 & 2.00 & 0.16 & 0.15 & 0.17 & 1.15 & 1.14 & 0.29 \\
\hline WL & 1 & 2.82 & 1.96 & 2.30 & 0.15 & 0.14 & 0.10 & 1.00 & 0.99 & 0.16 \\
\hline & 2 & 2.44 & 1.81 & 1.91 & 0.13 & 0.13 & 0.11 & 1.20 & 1.20 & 0.20 \\
\hline & 3 & 2.71 & 2.44 & 1.51 & 0.18 & 0.17 & 0.10 & 1.19 & 1.19 & 0.22 \\
\hline SL & 1 & 2.67 & 1.70 & 3.00 & 0.16 & 0.15 & 0.11 & 1.05 & 1.02 & 0.20 \\
\hline & 2 & 2.47 & 2.00 & 1.75 & 0.13 & 0.13 & 0.13 & 1.18 & 1.19 & 0.18 \\
\hline & 3 & 3.07 & 2.62 & 1.98 & 0.18 & 0.18 & 0.13 & 1.16 & 1.17 & 0.22 \\
\hline
\end{tabular}

Panel B: Pearson Correlation Of Variables

\begin{tabular}{|c|c|c|c|c|c|c|c|}
\hline \multirow{3}{*}{ Group } & \multirow{3}{*}{ Variable } & \multirow{2}{*}{\multicolumn{2}{|c|}{$\begin{array}{c}\text { Period 1 } \\
\text { (Year 1999-2001) } \\
\end{array}$}} & \multirow{2}{*}{\multicolumn{2}{|c|}{$\begin{array}{c}\text { Period 2 } \\
\text { (Year 2002-2004) } \\
\end{array}$}} & \multirow{2}{*}{\multicolumn{2}{|c|}{$\begin{array}{c}\text { Period 3 } \\
\text { (Year 2005-2007) } \\
\end{array}$}} \\
\hline & & & & & & & \\
\hline & & Price & EPS & Price & EPS & Price & EPS \\
\hline \multirow[t]{2}{*}{ Pool } & EPS & $0.43^{* *}$ & & $0.59 * *$ & & $0.64 * *$ & \\
\hline & $\mathrm{BV}$ & $0.38 * *$ & $0.53 * *$ & $0.30 * *$ & $0.61 * *$ & $0.38 * *$ & $0.51 * *$ \\
\hline \multirow[t]{2}{*}{ WH } & EPS & $0.33 * *$ & & $0.53 * *$ & & $0.58 * *$ & \\
\hline & $\mathrm{BV}$ & $0.38 * *$ & $0.45^{* *}$ & $0.32 * *$ & $0.74 * *$ & $0.39 * *$ & 0.56 ** \\
\hline \multirow[t]{2}{*}{$\mathrm{SH}$} & EPS & $0.39 * *$ & & $0.64 * *$ & & $0.64 * *$ & \\
\hline & $\mathrm{BV}$ & $0.44 * *$ & $0.66 * *$ & $0.46 * *$ & $0.60 * *$ & $0.45 * *$ & $0.56 * *$ \\
\hline \multirow[t]{2}{*}{ WL } & EPS & $0.55 * *$ & & $0.58 * *$ & & $0.72 * *$ & \\
\hline & $\mathrm{BV}$ & $0.31 * *$ & $0.45 * *$ & $0.11 *$ & $0.54 * *$ & $0.38 * *$ & $0.49 * *$ \\
\hline \multirow[t]{2}{*}{ SL } & EPS & $0.53 * *$ & & $0.60 * *$ & & $0.68 * *$ & \\
\hline & $\mathrm{BV}$ & $0.35^{* *}$ & $0.46 * *$ & $0.26 * *$ & $0.54 * *$ & $0.32 * *$ & $0.41 * *$ \\
\hline
\end{tabular}

Notes:

1. The sample is divided into 4 groups, based on the level of investor protection and firm characteristics which determine the use of managerial discretion.

- Group WH: Firms which operate in the country with weak investor protection (W) and have firm characteristics which allow/induce high use of managerial discretion $(\mathrm{H})$.

- Group SH: Firms which operate in the country with strong investor protection (S) but have firm characteristics which allow/induce high use of managerial discretion $(\mathrm{H})$.

- Group WL: Firms which operate in the country with weak investor protection (W) and have firm characteristics which allow/induce low use of managerial discretion (L).

- Group SL: Firms which operate in the country with strong investor protection (S) and have firm characteristics which allow/induce low use of managerial discretion (L).

2. Variable definition is as follows: Price is the closing price at the balance sheet date plus two months, EPS is earnings, and BV is book value of equity. These variables are per share basis and scaled by the beginning-of-period book value of equity.

3. $* *$ and * Correlation is significant at the 0.05 and 0.10 level (2-tailed), respectively. 
Panel A of Table 3 presents descriptive statistics on price, earnings and book value of equity. All variables are scaled by book value of equity at the time $\mathrm{t}-1$ in order to mitigate potential scale effect (Brown et al. 1999). The means of scaled price, earnings and book value of equity are $\$ 2.52, \$ 0.13$ and $\$ 1.12$, respectively. Standard deviation of price is higher than that of EPS and book value of equity, implying that the volatility of price is higher than that of accounting data. When dividing the sample by group and period, we found that Group WH and Group $\mathrm{SH}$, representing the firms having characteristics which allow or induce high use of discretion, have smaller average value of most variables than Group WL and Group SL, representing the firms having characteristics which allow or induce low use of discretion. In Panel B of Table 3, Pearson correlation of variables shows that both earnings and book value of equity are significantly correlated with price in all four groups and in all three periods.

\section{Regression Results}

Table 4 reports the regression results for the hypothesis. Panel A shows that earnings have increasing explanatory power in price after IFRS adoption. For Group WH and Group SH (i.e. the firms with characteristics that allow or induce high use of discretion), earning is not value-relevant during pre-IFRS adoption period (period 1), but become value-relevant after the official announcement of IFRS requirement (during period 2 and 3). During period 2 and period 3, earnings become value-relevant in all groups.

Panel B reports adjusted $\mathrm{R}^{2}$ of price regression, which is our measure for value relevance of earnings and book value of equity. The comparison of adjusted $R^{2}$ shows that there is significant improvement in adjusted $R^{2}$ after IFRS adoption for all groups, except Group WH. From period 1 (pre-IFRS adoption period) to period 3 (after IFRS adoption), adjusted $\mathrm{R}^{2}$ of Group SH, Group WL and Group SL increase by 0.19 to 0.22 . On the other hand, adjusted $\mathrm{R}^{2}$ of Group WH increases by only 0.11 , which is insignificant. This is consistent with our prediction that the firms which have the characteristics that allow/induce high use of managerial discretion and operate under weak investor protection environment are less likely to experience the improvement in value relevance after IFRS adoption.

Our findings have at least 2 implications. First, the result suggests that firm characteristics have important influence on the improvement in value relevance, resulting from IFRS adoption. This is evidenced as Group WL and Group SL, which have firm characteristics that allow or induce low use of discretion, experience significant improvement in value relevance (Adjusted $\mathrm{R}^{2}$ increase from period 1 to period 3 by 0.21 and 0.19 ). On the other hand, Group WH, which has the firm characteristics that allow or induce high use of discretion, does not exhibit any significant improvement in value relevance (Adjusted $R^{2}$ insignificantly increases from period 1 to period 3 by 0.11 ). Such difference highlights the importance of firm characteristics on the effectiveness of IFRS adoption.

Although Group WH and Group SH have similar firm characteristics which allow or induce high use of managerial discretion, their outcomes of IFRS adoption are different. Significant improvement is found in Group SH which operates in strong investor protection environment, but not in Group WH which operates in weak investor protection environment (Adjusted $\mathrm{R}^{2}$ increase from period 1 to period 3 by 0.11 for Group WH and by 0.22 for Group SH). This findings lead to the second implication that investor protection can help reduce the degree of managerial discretion, which may arise from firm characteristics that allow or induce high use of managerial discretion.

Additional analysis is conducted by comparing value relevance between different groups in each period. The result in Panel C shows that there is no significant difference in value relevance among four groups in Period 1 (before IFRS adoption). However, after IFRS adoption (Period 3), adjusted $\mathrm{R}^{2}$ of Group WH is the lowest at level of 0.34 and is significantly different from those of the remaining 3 groups, of which adjusted $\mathrm{R}^{2}$ are 0.45 to 0.52 . The adjusted $\mathrm{R}^{2}$ of Group WH is significantly lower than those of the remaining three groups by 0.11 to 0.18 . On the other hand, the difference of adjusted $\mathrm{R}^{2}$ among Group SH, Group WL, and Group SL are insignificant (the difference ranges from 0.04 to 0.07). The results suggest that the significant difference between Group WH and the remaining three groups occurs after IFRS adoption (Period 3). Consistent with Panel B, Panel C indicates that Group WL, SH, and SL show superior improvement in value relevance to Group WH after IFRS adoption. 
Table 4: Effect Of The Mandatory Adoption Of IFRS On Value Relevance Of Earnings And Book Value Of Equity, Conditional On Investor Protection And Firm Characteristics

$$
\mathbf{P}_{\mathrm{it}} / \mathrm{BV}_{\mathrm{it}-1}=\beta_{0}+\beta_{1} \text { EPS }_{\mathrm{it}} / \mathrm{BV}_{\mathrm{it}-1}+\beta_{2} \mathrm{BV}_{\mathrm{it}} / \mathrm{BV}_{\mathrm{it}-1}+\beta_{3} \text { DYEAR2 }_{\mathrm{it}}+\beta_{4} \text { DYEAR3 }_{\mathrm{it}}+\varepsilon_{\mathrm{it}}
$$

Panel A: Co-efficient of Regressions - by Group and Period

\begin{tabular}{|c|c|c|c|c|c|c|c|}
\hline & & \multicolumn{2}{|c|}{ Period 1 } & \multicolumn{2}{c|}{ Period 2 } & \multicolumn{2}{c|}{ Period 3 } \\
\hline Group & & EPS & BV & EPS & BV & EPS & BV \\
\hline WH & Co-efficient & 2.44 & 2.83 & 5.13 & $(0.75)$ & 5.25 & 0.68 \\
\hline & $t$-statistics & 1.32 & 1.58 & $4.95 * *$ & $(1.69)^{*}$ & $4.75 * *$ & 1.07 \\
\hline SH & Co-efficient & 2.28 & 4.64 & 5.32 & 1.35 & 6.56 & 0.96 \\
\hline & $t$-statistics & $1.72 *$ & $4.11^{* *}$ & $8.67 * *$ & $3.07 * *$ & $9.38^{* *}$ & $2.07 * *$ \\
\hline WL & Co-efficient & 11.39 & 1.29 & 12.64 & $(2.77)$ & 10.34 & 0.15 \\
\hline & $t$-statistics & $7.08^{* *}$ & 1.29 & $10.14 * *$ & $(3.98)^{* *}$ & $11.44^{* *}$ & 0.27 \\
\hline SL & Co-efficient & 12.07 & 2.19 & 8.72 & $(0.76)$ & 10.50 & 0.28 \\
\hline & $t$-statistics & $5.02^{* *}$ & $2.54 * *$ & $6.14^{* *}$ & $(1.00)$ & $8.77^{* *}$ & 0.51 \\
\hline
\end{tabular}

Panel B: Comparison Of Adjusted $\mathbf{R}^{2}$ Between Different Periods

\begin{tabular}{|c|c|c|c|c|c|c|}
\hline & \multicolumn{3}{|c|}{ Adjusted R $^{\mathbf{2}}$} & \multicolumn{3}{c|}{ Difference of R $\mathbf{R}^{2}$ between period } \\
\hline Group & Period 1 & Period 2 & Period 3 & 1 vs 2 & 2 vs 3 & 1 vs 3 \\
\hline WH & 0.23 & 0.32 & 0.34 & 0.08 & 0.02 & 0.11 \\
\hline SH & 0.23 & 0.47 & 0.45 & $0.24^{* *}$ & $(0.02)$ & $0.22^{* *}$ \\
\hline WL & 0.31 & 0.38 & 0.52 & 0.07 & $0.14^{* *}$ & $0.21^{* *}$ \\
\hline SL & 0.29 & 0.39 & 0.49 & $0.10^{* *}$ & $0.09^{* *}$ & $0.19^{* *}$ \\
\hline
\end{tabular}

Panel C: Difference Of Adjusted $\mathbf{R}^{2}$ Among Different Groups (By Period)

\begin{tabular}{|c|c|c|c|c|c|c|c|c|c|}
\hline \multirow[b]{3}{*}{ Group } & \multicolumn{3}{|c|}{ Period 1} & \multicolumn{3}{|c|}{ Period 2} & \multicolumn{3}{|c|}{ Period 3} \\
\hline & \multicolumn{3}{|c|}{ Difference of $R^{2}$ between } & \multicolumn{3}{|c|}{ Difference of $\mathrm{R}^{2}$ between } & \multicolumn{3}{|c|}{ Difference of $R^{2}$ between } \\
\hline & WH & SH & WL & WH & SH & $\mathbf{W L}$ & WH & SH & $\mathbf{W L}$ \\
\hline $\mathrm{SH}$ & $(0.002)$ & & & $0.154 * *$ & & & $0.109 *$ & & \\
\hline WL & 0.075 & 0.077 & & 0.064 & $(0.09)$ & & $0.183 * *$ & 0.074 & \\
\hline SL & 0.055 & 0.057 & $(0.020)$ & 0.075 & $(0.079)^{*}$ & 0.011 & $0.145 * *$ & 0.036 & $(0.038)$ \\
\hline
\end{tabular}

Notes:

1. Variable definition are as follows: $\mathrm{P}$ is the closing price at the balance sheet date plus two months, EPS is earnings, and BV is book value of equity. These variables are per share basis and scaled by the beginning-of-period book value of equity. DYEAR2 is the dummy variable for Year 2 in each period, which is equal to 1 for the year 2000, 2003, and 2006; and 0 otherwise. DYEAR3 is the dummy variable for Year 3 in each period, which is equal to 1 for the year 2001, 2004, and 2007; and 0 otherwise.

2. The sample is divided into 4 sub-samples, based on investor protection and firm characteristics which determine the use of managerial discretion, which are as follows:

- Group WH: Firms which are in the country with weak investor protection (W) and have firm characteristics which allow/induce high use of managerial discretion $(\mathrm{H})$.

- Group SH: Firms which are in the country with strong investor protection (S) but have firm characteristics which allow/induce high use of managerial discretion $(\mathrm{H})$.

- Group WL: Firms which are in the country with weak investor protection (W) and have firm characteristics which allow/induce low use of managerial discretion $(\mathrm{L})$.

- Group SL: Firms which are in the country with strong investor protection (S) and have firm characteristics which allow/induce low use of managerial discretion $(\mathrm{L})$.

3. For the purpose of partitioning, investor protection is represented by anti-director rights index (La Porta et al., 1998).

For firm-level factor, the score is computed based on four firm characteristics, i.e. average firm size, cash flow from operation volatility, sales volatility, and incidence of negative earnings. For each variable, the sample is ranked. Low rank is assigned for the firms with low managerial incentive for accounting manipulation, i.e. large firm size, low sales volatility, low cash flow volatility and low incidence of negative earnings. Then, the ranks based on these 4 variables are averaged in order to get the score. Mean of this score is used as the cutoff point.

4. When heteroscedasticity problem is identified, standard errors are calculated using White (1980) heteroscedasticity-consistent variancecovariance matrix.

5. To determine whether adjusted R-squares of two sub-samples are significantly different, Z-statistics are calculated to estimate the probability to accept null hypothesis of equality of $\mathrm{R}^{2}$ (Harris et al., 1994 and Arce and Mora, 2002).

$$
\mathrm{Z}=\frac{\mathrm{R}_{1}^{2}-\mathrm{R}_{2}^{2}}{\sqrt{{\left.\sigma^{2} \mathrm{R}^{2} 1\right)}^{2}+\sigma_{(\mathrm{R} 2)}^{2}}}
$$

$\mathrm{R}_{1}^{2}$ and $\mathrm{R}_{2}^{2}$ are the $\mathrm{R}^{2}$ from the regressions of the subsamples being compared. $\sigma_{(\text {.) }}^{2}$ is their variance, which is calculated based on Cramer (1987).

6. $\quad * *$ and $*$ denote $5 \%$ and $10 \%$ significance, respectively (two-tailed). 
In sum, the findings provide supporting evidence for the improvement in value relevance after the adoption of IFRS in most cases. However, whether IFRS adoption leads to the improvement in value relevance depends on both level of investor protection (country-level factor) and firm characteristics which determine the use of managerial discretion (firm-level factor).

\section{CONCLUSION}

We investigate the effect of country-level and firm-level factors on the effectiveness of IFRS adoption by European Union countries. To determine whether IFRS adoption leads to improvement in the quality of accounting information, we use value relevance of earnings and book value of equity as our proxy for the quality of accounting information.

The analysis provides evidence that there is improvement in value relevance after IFRS adoption. This is consistent with prior literature which suggests that adopting international accounting standards leads to better quality of accounting information. However, among the sub-samples with different level of investor protection and different firm characteristics, we do not find any significant improvement in value relevance for the firms which operate in weak investor protection environment and have firm characteristics which allow or induce high use of managerial discretion.

Our findings suggest that whether IFRS adoption leads to the improvement in value relevance depends on level of investor protection (country-level factor) and firm characteristics (firm-level factor). The results report significant improvement in value relevance for Group SH, but not for Group WH. While both groups have firm characteristics which allow or induce high use of managerial discretion, the firms in strong investor protection environment (Group SH) still exhibit significant improvement. The findings highlight the importance of investor protection. Investor protection can help reduce the financial report preparer's incentive for accounting manipulation, which may arise from firm characteristics that allow or induce high use of managerial discretion. This is consistent with prior literature that the quality of accounting information is higher in strong investor protection environment (Hung, 2001).

In term of firm-level factor, our results suggest that firm characteristics can also affect the improvement from IFRS adoption, particularly when the firms operate in weak investor protection environment. In such case, without investor protection, there is no mechanism to reduce the incentive of the managers to expropriate against minorities, and in turn, their incentives to manipulate accounting numbers to conceal their fraud. Therefore, in weak investor protection environment, firm characteristics play important influence on the degree of improvement in value relevance, resulting from IFRS adoption.

Our findings have implications for standard setters and investors. The evidence that value relevance of accounting information improves after the mandatory adoption of IFRS supports the current effort of national standard setters to converge their accounting standards to IFRS. However, our findings also highlight the importance of other factors which could affect the financial report preparer's incentive, for example, investor protection and firm characteristics.

It reminds national standard setters about the importance of investor protection. In the case where the firm have characteristics which induce high use of managerial discretion (for example, high cash flow volatility, high sales volatility, frequent incidence of losses), investor protection can be an effective tool to reduce the financial report preparer's incentive for accounting manipulation. Therefore, it is important for national standard setters not to just adopt IFRS on paper but to simultaneously strengthen investor protection- through both legal and market mechanism - in order to promote the compliance with the standards.

Also, our findings raise awareness to investors and other financial report users that they should not be misled by the word "accounting standard harmonization". The mandatory adoption of IFRS does not guarantee consistent implementation of IFRS across firms, since there are other factors which affect the financial report preparer's incentive, and in turn, their accounting practices. Caution is needed, especially when reading financial reports of the firms, of which the characteristics allow or induce high use of managerial discretion. This is 
especially important when investor protection is weak, as there is no mechanism to reduce high use of managerial discretion.

However, our study has limitations in term of unavailability of data used to calculate firm-level score. While four firm characteristics (i.e. firm size, cash flow volatility, sales volatility, and incidence of negative earnings) are used in this paper, future research can include other relevant firm characteristics, for example, earnings volatility, length of operating cycle, investment opportunities, and insider ownership. In addition, the analysis can be extended to other attributes of accounting quality, such as conservatism or earnings management.

Our findings highlight the importance of investor protection. Other aspects of legal and market factors which affect the investor protection can be explored. For example, the effectiveness of securities market regulator can affect accounting practices of accounting professionals. As the incentive of other stakeholders involved in financial reporting process under fair value accounting, for example auditor or real estate appraiser, can influence the quality of accounting information, regulation and enforcement governing these stakeholders should be explored.

\section{ACKNOWLEDGEMENT}

We appreciate the helpful comments of the participants at the 11th Annual Conference of the Asian Academic Accounting Association (AAAA)

\section{AUTHOR INFORMATION}

Kanogporn Narktabtee, Ph.D. is an assistant professor of Accounting at Graduate School of Business Administration at National Institute of Development Administration (NIDA) in Thailand. She holds a Ph.D. in Accounting (University of Arkansas, Fayetteville). She focuses on financial reporting and issues in accounting standards. E-mail: kanogp.n@nida.ac.th

Suntaree Patpanichchot, DBA is a graduate of Joint Doctoral Program in Business Administration (JDBA) at National Institute of Development Administration (NIDA), Thailand. The JDBA program is co-organized by Chulalongkorn University, Thammasat University, and National Institute of Development Administration. E-mail: suntareepat@yahoo.com

\section{REFERENCES}

1. Alford, A., Jones, J., Leftwich, R. and Zmijewski, M., 1993. The relative informativeness of accounting disclosures in different countries. Journal of Accounting Research 31 (3), 183-223.

2. Ali, A. and Hwang, L., 2000. Country-specific factors related to financial reporting and the value relevance of accounting data. Journal of Accounting Research 38 (Spring), 1-21.

3. Amir, E., Harris, T. S. and Venuti, E. K., 1993. A comparison of the value-relevance of U.S. versus NonU.S. GAAP accounting measures using Form 20-F reconciliations. Journal of Accounting Research 31 (3), 230-264.

4. Arce, M. and Mora, A., 2002. Empirical evidence of the effect of European accounting differences on the stock market valuation of earnings and book value. The European Accounting Review 11 (September), 573-599.

5. Ashbaugh, H. and Pincus, M., 2001. Domestic accounting standards, international accounting standards, and the predictability of earnings. Journal of Accounting Research 39 (December), 417-434.

6. Atiase, R.K., 1985. Predisclosure information, firm capitalization, and security price behavior around earnings announcements. Journal of Accounting Research 23(1), 21-36.

7. Auer, K.V., 1996. Capital market reactions to earnings announcements: empirical evidence on the difference in the information content of IAS-based earnings and EC-directives-based earnings. The European Accounting Review 5 (4), 587-623.

8. Ball, R., 2006. International financial reporting standards (IFRS): pros and cons for investors. Accounting and Business Research 36 (Special Issue), 5-27. 
9. Barth, M. E., Landsman, W. R. and Lang, M. H., 2008. International accounting standards and accounting quality. Journal of Accounting Research 46 (June), 467-498.

10. Boonlert-U-Thai, K., Meek, G. K. and Nabar, S., 2006. Earnings attributes and investor-protection: international evidence. The International Journal of Accounting 41 (December), 327-357.

11. Brown, S., Lo, K. and Lys, T., 1999. Use of $\mathrm{R}^{2}$ in accounting research: measuring changes in value relevance over the last four decades. Journal of Accounting and Economics 28 (December), 83-115.

12. Bushman, R.M. and Piotroski, J.D., 2006. Financial reporting incentives for conservative accounting: the influence of legal and political institutions. Journal of Accounting and Economics 42 (October), 107-148.

13. Callao, S. and Jarne, J., 2010. Have IFRS affected earnings management in the European Union? Accounting in Europe 7 (2), 159-190.

14. Cramer, J. S., 1987. Mean and variance of $\mathrm{R}^{2}$ in small and moderate samples. Journal of Econometrics 35 (July), 253-266.

15. Dechow, P. and Dichev, I., 2002. The quality of accruals and earnings: the role of accrual estimation errors. The Accounting Review 77 (Suppl.), 35-39.

16. Defond, M., Hung, M. and Trezevant, R., 2007. Investor protection and the information content of annual earnings announcements: international evidence. Journal of Accounting and Economics 43 (March), 37-67.

17. Eierle, B. and Haller, A., 2009. Does size influence the suitability of the IFRS for small and medium-sized entities? - Empirical evidence from Germany. Accounting in Europe 6 (1-2), 195-230.

18. Fan, J. P.H. and Wong, T.J., 2002. Corporate ownership structure and the informativeness of accounting earnings in East Asia. Journal of Accounting and Economics 33 (August), 401-425.

19. Freeman, R.N., 1987. The association between accounting earnings and security return for large and small firms. Journal of Accounting Economics 9, 195-228.

20. Gaio, C., 2010. The relative importance of firm and country characteristics for earnings quality around the world. European Accounting Review (iFirst Article), 1-46.

21. Harris, T. S., Lang, M. and Moller, H., 1994. The value relevance of German accounting measures: an empirical analysis. Journal of Accounting Research 32 (Autumn), 187-209.

22. Hung, M., 2001. Accounting standards and value relevance of financial statements: an international analysis. Journal of Accounting and Economics 30 (December), 401-420.

23. Joos, P. and Lang, M., 1994. The effects of accounting diversity: Evidence from the European Union. Journal of Accounting Research 32 (3, Suppl.), 141-168.

24. La Porta, R., Lopez-de-Silanes, F., Shleifer, A. and Vishny, R., 1997. Legal determinants of external finance. Journal of Finance 52 (July), 1131-1150.

25. La Porta, R., Lopez-de-Silanes, F., Shleifer, A. and Vishny, R., 1998. Law and finance. Journal of Political Economy 106 (December), 1113-1155.

26. La Porta, R., Lopez-de-Silanes, F., Shleifer, A. and Vishny, R., 2000. Investor protection and corporate governance. Journal of Financial Economics 58(October/November), 3-27.

27. La Porta, R., Lopez-de-Silanes, F., Shleifer, A. and Vishny, R., 2002. Investor protection and corporate valuation. Journal of Finance 57 (June), 1147-1170.

28. Luez, C., Nanda, D. and Wysocki, P. D., 2003. Earnings management and investor protection: an international comparison. Journal of Financial Economics 69 (September), 505-527.

29. Minton, B. and Schrand, C., 1999. The impact of cash flow volatility on discretionary investment and the costs of debt and equity financing. Journal of Financial Economics 54, 423-460.

30. Ohlson, J. A., 1991. The theory of value and earnings, an introduction to the Ball-Brown analysis. Contemporary Accounting Research 8 (Fall), 1-19. 